\title{
The presence of a $\mathrm{Zn}^{2+}$-dependent acid p-nitrophenyl phosphatase in bovine liver
}

\author{
Isolation and some properties
}

Fausto PANARA

Istituto di Biologia Cellulare, Facoltá di Scienze MM.FF.NN., via Elce di Sotto, Universitá di Perugia, 06100 Perugia, Italy

\begin{abstract}
1. The presence of a $\mathrm{Zn}^{2+}$-dependent acid p-nitrophenyl phosphatase (EC 3.1.3.2) in bovine liver was described. 2. The enzyme was purified to apparent homogeneity and migrates as a single band during electrophoresis on polyacrylamide gel. 3. The enzyme requires $\mathrm{Zn}^{2+}$ ions for catalytic activity, other bivalent cations have little or no effect. 4. The enzyme, of $M_{\mathrm{r}} 118000$, optimum pH 6-6.2 and pI 7.4-7.5, was inhibited by EDTA, tartrate, adenine and ATP, but not by fluoride. 5. The common phosphate esters are poor substrates for the enzyme, which hydrolyses preferentially $p$-nitrophenyl phosphate and $o$-carboxyphenyl phosphate. 6 . The $\mathrm{Zn}^{2+}$-dependent acid $p$-nitrophenyl phosphatase of bovine liver was different from the high- $M_{\mathrm{r}}$ acid phosphatases previously detected in mammalian tissues.
\end{abstract}

\section{INTRODUCTION}

Acid phosphatases are ubiquitous enzymes, which have been studied in plants and animals (see Hollander, 1971). Mammalian liver contains at least two acid phosphatase forms, of $M_{\mathrm{r}} 90000-102000$ and 13400-30000, which can be separated by gel-exclusion chromatography (Heinrikson, 1969; Campbell et al., 1973; Rehkop \& Van Etten, 1975; De Araujo et al., 1976). The effect of inhibitors, substrate requirements, optimum $\mathrm{pH}$ and kinetic parameters also distinguish between the enzymes (Shibko \& Tappel, 1963; Heinrikson, 1969; Baldijao et al., 1975; De Araujo et al., 1976; Saini \& Van Etten, 1978a ; Taga \& Van Etten, 1982).

Most of the acid phosphatase activity in bovine liver was associated with the low- $M_{\mathrm{r}}$ enzyme, which was purified to homogeneity (Heinrikson, 1969; Lawrence \& Van Etten, 1981). In the present paper I describe the presence in bovine liver of a high- $M_{\mathrm{r}}$ form of acid phosphatase which requires $\mathrm{Zn}^{2+}$ ions for activity. The enzyme has been purified and partially characterized.

\section{EXPERIMENTAL}

\section{Materials}

Substrates, modifiers, Folin reagent and $M_{\mathrm{r}}$ markers were purchased from Sigma. Sephadex G-200 was from Pharmacia, and DEAE- and CM-cellulose were from Whatman. Other chemicals were obtained from Carlo Erba. All reagents were made with demineralized and double-distilled water.

\section{Methods}

Enzyme assays. Phosphatase activity was determined at $37^{\circ} \mathrm{C}$ in $50 \mathrm{~mm}$-sodium acetate buffer, $\mathrm{pH} 6$, containing $2.5 \mathrm{~mm}$-p-nitrophenyl phosphate and $4 \mathrm{~mm}-\mathrm{ZnCl}_{2}$. The reaction was started by addition of enzyme solution in a final volume of $0.5 \mathrm{ml}$. After $5-10 \mathrm{~min}$ the reaction was stopped by adding $1-2.5 \mathrm{ml}$ of $1 \mathrm{M}-\mathrm{NaOH}$, and the $A_{415}$ of the liberated $p$-nitrophenol was read $\left(\epsilon_{415}=1.78 \times 10^{4} \mathrm{M}^{-1} \cdot \mathrm{cm}^{-1}\right)$. One enzyme unit is defined as the amount of enzyme that produces $1 \mu \mathrm{mol}$ of $p$-nitrophenol $/ \mathrm{min}$. Specific activity was expressed as enzyme units per $\mathrm{mg}$ of protein, determined as described by Lowry et al. (1951).

The $\mathrm{pH} /$ activity curves were obtained in $50 \mathrm{~mm}$-acetate (pH 4-6.2), 25 mm-barbital (pH 6-9) or $50 \mathrm{~mm}$-glycine/ $\mathrm{NaOH}$ (pH 8.8-9.6).

The effect of metal ions was assayed at fixed $2.5 \mathrm{~mm}$ $p$-nitrophenyl phosphate concentration, with different metal ion concentrations. The effect of modifiers was tested at various concentrations in the presence of $4 \mathrm{~mm}-\mathrm{ZnCl}_{2}$.

$K_{\mathrm{m}}$ was obtained by the statistical method of Wilkinson (1961), including S.E.M., with ten substrate concentrations ranging from 0.2 to $2.5 \times K_{\mathrm{m}}$. The hydrolysis of various phosphate esters ( $5 \mathrm{~mm}$ final concn.) was assayed at $37^{\circ} \mathrm{C}$ in $50 \mathrm{~mm}$-acetate buffer, $\mathrm{pH} 6$, as described by Saini \& Van Etten (1978a). The ionic strength, $I$, was maintained at $0.15 \mathrm{M}$ in in all enzyme assays by addition of $\mathrm{NaCl}$ (Van Etten \& McTigue, 1977).

Analytical polyacrylamide-gel electrophoresis was carried out on $7.5 \%$ acrylamide gels at $\mathrm{pH} 8.3$ (Davis, 1964). The gels were cut into $2 \mathrm{~mm}$ slices and eluted overnight in $200 \mu \mathrm{l}$ of $0.2 \mathrm{M}$-sodium acetate buffer, $\mathrm{pH} 6$. Enzyme activity was assayed by adding $400 \mu \mathrm{l}$ of $5 \mathrm{~mm}$ - -nitrophenyl phosphate and $4 \mathrm{~mm}-\mathrm{ZnCl}_{2}$. After $1 \mathrm{~h}$ at $37^{\circ} \mathrm{C}$ the reaction was stopped by $400 \mu \mathrm{l}$ of $1 \mathrm{M}-\mathrm{NaOH}$, and the $A_{415}$ of each fraction was read. The proteins were stained as described by Malik \& Berrie (1972).

The pI was determined by isoelectric focusing on polyacrylamide gel as described by Drysdale et al. (1971), by using ampholytes in the $\mathrm{pH}$ range $5-8$ or 7-9. Electrophoresis was run at $1 \mathrm{~mA} /$ tube until the voltage reached a value of $400 \mathrm{~V}$ (about 80-90 min), and then a constant voltage was maintained for another $1 \mathrm{~h}$. Enzyme activity was assayed on sliced gel as described above. Control gels were sliced and eluted in $1 \mathrm{ml}$ of deionized distilled water for $\mathrm{pH}$ profiles.

The apparent $M_{\mathrm{r}}$ was estimated on a calibrated Sephadex G-200 column $(1.8 \mathrm{~cm} \times 85 \mathrm{~cm})$ by comparing the elution volumes of the following standards: bovine 


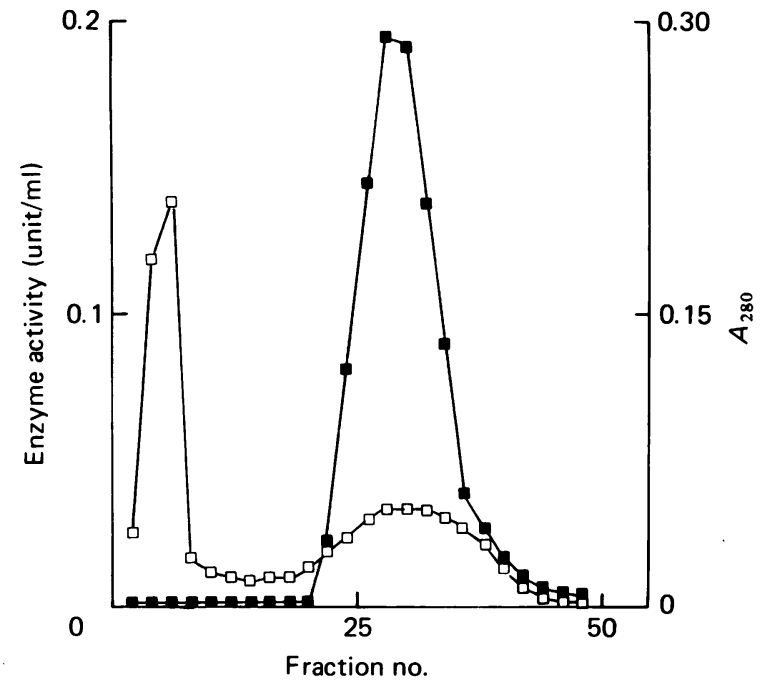

Fig. 1. Elution profile of $\mathrm{Zn}^{2+}$-dependent acid p-nitrophenyl phosphatase from the CM-cellulose column equilibrated in $10 \mathrm{mM}$-acetate buffer, $\mathrm{pH} 6$

The sample was loaded and the proteins were eluted with a linear gradient of $0-0.3 \mathrm{M}-\mathrm{NaCl}$ in equilibration buffer; $6 \mathrm{ml}$ fractions were collected at a flow rate of $45 \mathrm{ml} / \mathrm{h} . \square$, $A_{280}$ (protein); $\square$, enzyme activity.

$\gamma$-globulin $\left(M_{\mathrm{r}}\right.$ 158000), bovine serum albumin (67000), ovalbumin (45000) and lysozyme (14000). The void volume was determined with Blue Dextran. The correlation coefficient of a plot of the mobility of standards against $\log M_{\mathrm{r}}$ was 0.998 .

Enzyme purification. The data reported in this paper refer to $50 \mathrm{~g}$ of fresh bovine liver. All operations were performed at $4{ }^{\circ} \mathrm{C}$. The tissue was washed twice in cold $0.25 \mathrm{~m}$-sucrose/1 mM-EDTA/5 mM-Tris/HCl buffer, $\mathrm{pH} \mathrm{7.4,} \mathrm{and} \mathrm{then} \mathrm{immersed} \mathrm{in} 0.3 \mathrm{M}$-acetate buffer, pH 6, and homogenized in a Potter-Elvehjem homogenizer. The homogenate was made up to $130 \mathrm{ml}$ with acetate buffer and gently stirred for $4 \mathrm{~h}$. The extract was centrifuged at $45000 \mathrm{~g}$ for $90 \mathrm{~min}$ and the pellet discarded. The supernatant $(100 \mathrm{ml})$ was dialysed against $20 \mathrm{vol}$. of $50 \mathrm{~mm}$-acetate buffer, $\mathrm{pH} \mathrm{6}$, and then fractionated with $\left(\mathrm{NH}_{4}\right)_{2} \mathrm{SO}_{4}$. The fraction obtained between 30 and $70 \%$ saturation was resuspended in $20 \mathrm{ml}$ of $50 \mathrm{~mm}$-acetate (pH 6) and adjusted to $\mathrm{pH} 4.5$ with cold $1 \mathrm{M}$-acetic acid. After centrifugation at $45000 \mathrm{~g}$ for $20 \mathrm{~min}$, the supernatant was dialysed against $50 \mathrm{~mm}$-acetate buffer, $\mathrm{pH} \mathrm{6,} \mathrm{containing} 0.1 \mathrm{M}-\mathrm{NaCl}$. The sample (about 25-30 ml) was divided into two batches, and each was loaded on to a Sephadex G-200 column $(3 \mathrm{~cm} \times 65 \mathrm{~cm})$ equilibrated with the dialysis buffer; $10 \mathrm{ml}$ fractions were collected at a rate of $15 \mathrm{ml} / \mathrm{h}$ and assayed for enzyme activity. The pooled fractions containing more than 0.1 unit $/ \mathrm{ml}$ were concentrated by $70 \%$ saturation with $\left(\mathrm{NH}_{4}\right)_{2} \mathrm{SO}_{4}$, and resuspended in $0.1 \mathrm{vol}$ of $10 \mathrm{mM}$-Tris/ $\mathrm{HCl}$ buffer, $\mathrm{pH} \mathrm{7.4,} \mathrm{and} \mathrm{dialysed} \mathrm{in} \mathrm{the} \mathrm{same}$ buffer. The enzyme solution (about 14-16 ml) was poured on to a DEAE-cellulose column $(2 \mathrm{~cm} \times 20 \mathrm{~cm})$, equilib-

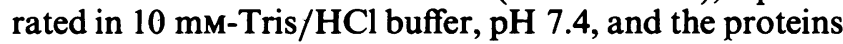
were eluted with a linear $\mathrm{NaCl}$ gradient $(0-0.1 \mathrm{M}$, in $600 \mathrm{ml}$ of Tris buffer. Fractions $(6 \mathrm{ml})$ were collected at $45 \mathrm{ml} / \mathrm{h}$ and assayed as described above. The fractions containing more than 0.1 unit $/ \mathrm{ml}$ were pooled, dialysed against

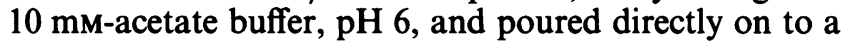
column $(2 \mathrm{~cm} \times 10 \mathrm{~cm})$ of CM-cellulose equilibrated in the same buffer. The proteins were eluted with a linear $\mathrm{NaCl}$ gradient $(0-0.3 \mathrm{M} ; 500 \mathrm{ml})$ in equilibration buffer, and $6 \mathrm{ml}$ fractions were collected at $45 \mathrm{ml} / \mathrm{h}$. The phosphatase activity was eluted as a single protein peak of constant specific activity after a protein peak with no phosphatase activity (Fig. 1). The fractions containing activity were pooled (about $80-90 \mathrm{ml}$ ) and used for biochemical analysis or concentrated by dialysing the enzyme solution against $10 \mathrm{~mm}$-acetate buffer, $\mathrm{pH} 6$, and then adsorbing it on to a micro-column of CM-cellulose $(1 \mathrm{~cm} \times 1.5 \mathrm{~cm})$. The enzyme was eluted in a single step with $0.5 \mathrm{M}-\mathrm{NaCl}$. This operation gives a $40-50$-fold concentration of the enzyme preparation.

\section{RESULTS AND DISCUSSION}

Acid phosphatases originating from many sources have been found to need metal ions for their activity. In the chicken, Wang (1969) and Strittmatter (1972) demonstrated the presence of a soluble form of acid $p$-nitrophenyl phosphatase, stimulated by $\mathrm{Zn}^{2+}$, in the liver and duodenum during embryonic development. A $\mathrm{Zn}^{2+}$ stimulated acid phosphatase has also been reported in rat testicular tissues (Vanha-Perttula, 1970) and rabbit spermatozoa (Gonzales \& Meizel, 1973). These enzymes, however, were studied only as crude preparations (Wang, 1969) or in a partially purified form (Strittmatter, 1972; Gonzales \& Meizel, 1973) In the present paper I demonstrate the presence of $\mathrm{Zn}^{2+}$-dependent acid $p$-nitrophenyl phosphatase in bovine liver. The enzyme was purified to apparent homogeneity and migrates as a single protein band on polyacrylamide-gel electrophoresis (Fig. 2). A summary of a typical preparation is presented in Table 1 . The purified enzyme, with a specific activity of $10 \mathrm{units} / \mathrm{mg}$ of protein, is stable for 1 week at $4^{\circ} \mathrm{C}$, and no loss of activity was observed when it was stored in dilute solution at $-20^{\circ} \mathrm{C}$ for several months.

The effect of various concentrations of $\mathrm{ZnCl}_{2}, \mathrm{MnCl}_{2}$ and $\mathrm{CoCl}_{2}$ on $p$-nitrophenyl phosphate hydrolysis (Fig. 3) indicates that $\mathrm{Zn}^{2+}$ was necessary for stimulating the catalytic activity of the enzyme, the optimal concentration being 3-5 mM. $\mathrm{Mn}^{2+}$ could substitute for $\mathrm{Zn}^{2+}$, but gave only $15-20 \%$ activation. $\mathrm{Co}^{2+}$ and other bivalent cations, including $\mathrm{Mg}^{2+}, \mathrm{Ca}^{2+}, \mathrm{Ba}^{2+}, \mathrm{Be}^{2+}, \mathrm{Sn}^{2+}, \mathrm{Pb}^{2+}, \mathrm{Ni}^{2+}$ and $\mathrm{Fe}^{2+}$, showed no effect. The optimal $\mathrm{pH}$ for the enzyme was about 6-6.2 in the presence of either $4 \mathrm{mM}-\mathrm{ZnCl}_{2}$ or $4 \mathrm{~mm}^{-\mathrm{MnCl}_{2}}$ (Fig. 4). No shift in the pH optimum was produced by varying the metal concentration.

The $\mathrm{Zn}^{2+}$-dependent acid $p$-nitrophenyl phosphatase of bovine liver was insensitive to $\mathrm{NaF}$, and $50 \%$ inhibition was observed with $5 \mathrm{mM}-\mathrm{L}(+)$-tartrate, $2 \mathrm{~mm}$ EDTA, $1 \mathrm{~mm}$-adenine and $2.5 \mathrm{~mm}$-ATP. The enzyme is strongly inactivated by $0.5 \mathrm{~mm}$ - $p$-chloromercuribenzoate or $1 \mathrm{mM}-\mathrm{Ag}^{+}$or $-\mathrm{Hg}^{2+}$.

The rates of hydrolysis of various phosphate esters indicate that $p$-nitrophenyl phosphate and $o$-carboxyphenyl phosphate were hydrolysed rapidly by the bovine liver enzyme. The activity towards phenyl phosphate was only $15 \%$ of that measured for $p$-nitrophenyl phosphate. Other commonly used phosphate esters, including $\alpha$-naphthyl phosphate, $\beta$-glycerophosphate, $O$-phosphoL-serine, ATP, ADP and AMP are not hydrolysed at a 


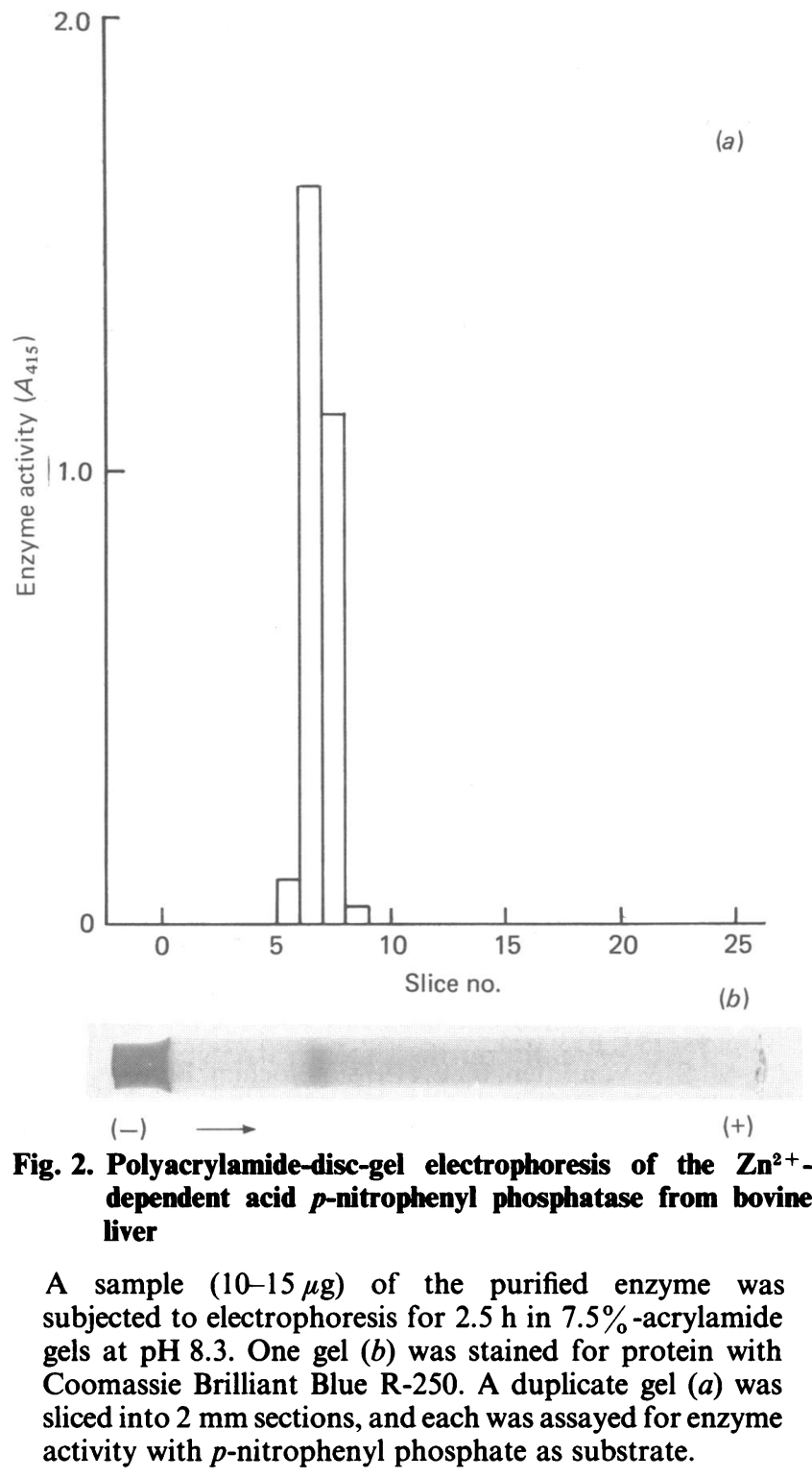

measurable rate. The enzyme preparation is devoid of diphosphatase and pyrophosphatase activities.

The Michaelis constant for $p$-nitrophenyl phosphate determined at pH 6 is $0.38 \pm 0.04 \mathrm{~mm}$. The $M_{\mathrm{r}}$ determination gives a value of 118000 ; the variation of three independent experiments was about $5 \%$. Electrofocusing on polyacrylamide gel shows a single peak of enzyme activity with a pI of 7.45-7.50.

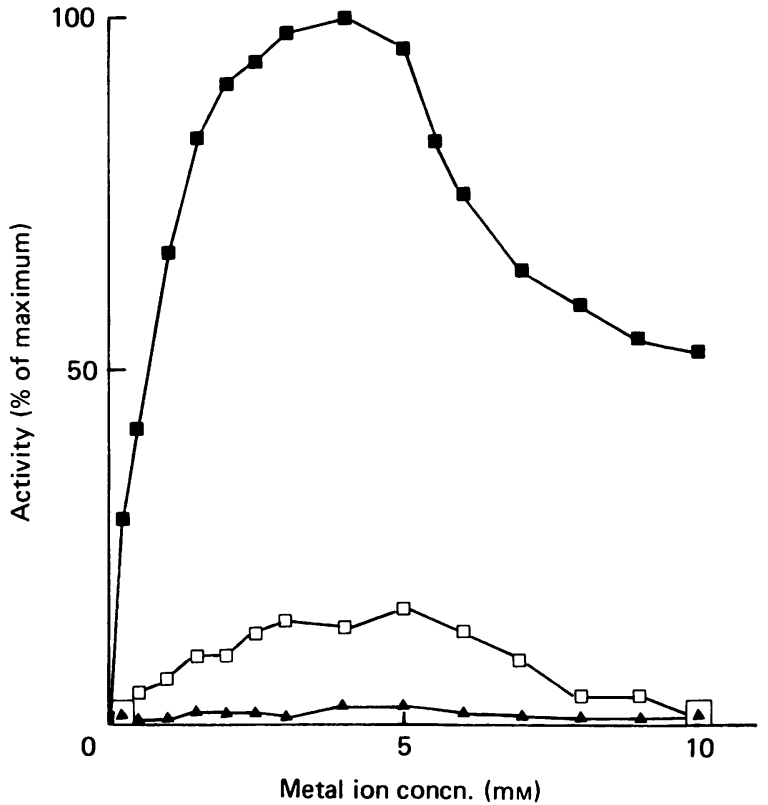

Fig. 3. Effect of metal ions concentration on activity of purified acid $p$-nitrophenyl phosphatase from bovine liver

Assays were carried out at $37^{\circ} \mathrm{C}$ with $2.5 \mathrm{~mm}$-p-nitrophenyl phosphate, 50 mm-acetate buffer, $\mathrm{pH} \mathrm{6}$, and metal ion at the desired concentration. Each point was an average of three experiments. The maximum activity was expressed by taking the highest activity in any fraction as $100 \%$, and the other activities were expressed as a percentage of the maximum activity. $\square, \mathrm{Zn}^{2+} ; \square, \mathrm{Mn}^{2+} ; \mathbf{\Lambda}, \mathrm{Co}^{2+}$.

The $\mathrm{Zn}^{2+}$-dependent acid $p$-nitrophenyl phosphatase of bovine liver seems to be very similar to that of chick-embryo liver and duodenum with respect to $\mathrm{Zn}^{2+}$ stimulation, optimum $\mathrm{pH}$ and inhibition by adenine nucleotides (Wang, 1969; Strittmatter, 1972). The negligible activation by $\mathrm{Mn}^{2+}, \mathrm{Co}^{2+}$ and $\mathrm{Mg}^{2+}$, the apparent $M_{\mathrm{r}}$ and substrate specificity differentiate this enzyme from that of rat testicular tissue (Vanha-Perttula, 1970) and rabbit spermatozoa (Gonzales \& Meizel, 1973).

The $M_{\mathrm{r}}$ of 118000 is similar to that reported for the high- $M_{\mathrm{r}}$ acid phosphatases from mammalian liver (Igarashi \& Hollander, 1968; Campbell et al., 1973; Saini \& Van Etten, 1978a,b), prostatic (Luchter-Wasyl \& Ostrowsky, 1974; Saini \& Van Etten, 1978b) and placental tissue (Di Pietro \& Zengerle, 1967). These enzymes, however, were not stimulated by $\mathrm{Zn}^{2+}$, showed an optimal $\mathrm{pH}$ in the more acidic region (pH 4.5-5.5) and were strongly inactivated by $\mathrm{NaF}$.

Table 1. Summary of purification of the $\mathrm{Zn}^{2+}$-dependent acid p-nitrophenyl phosphatase of bovine liver

\begin{tabular}{lcccc}
\hline & $\begin{array}{c}\text { Protein } \\
\text { (mg) }\end{array}$ & $\begin{array}{c}\text { Activity } \\
\text { (units) }\end{array}$ & $\begin{array}{c}\text { Specific } \\
\text { activity (units/ } \\
\text { mg of protein) }\end{array}$ & $\begin{array}{c}\text { Recovery } \\
(\%)\end{array}$ \\
\hline Liver extract & 5800 & 168 & 0.029 & 100 \\
$\left(\mathrm{NH}_{4}\right)_{2} \mathrm{SO}_{4}$ fractionation & 3650 & 120 & 0.033 & 71 \\
pH fractionation & 2200 & 96 & 0.043 & 57 \\
Sephadex G-200 & 420 & 54 & 0.128 & 32 \\
DEAE-cellulose & 28 & 38 & 1.36 & 22 \\
CM-cellulose & 1.2 & 12 & 10.00 & 7
\end{tabular}




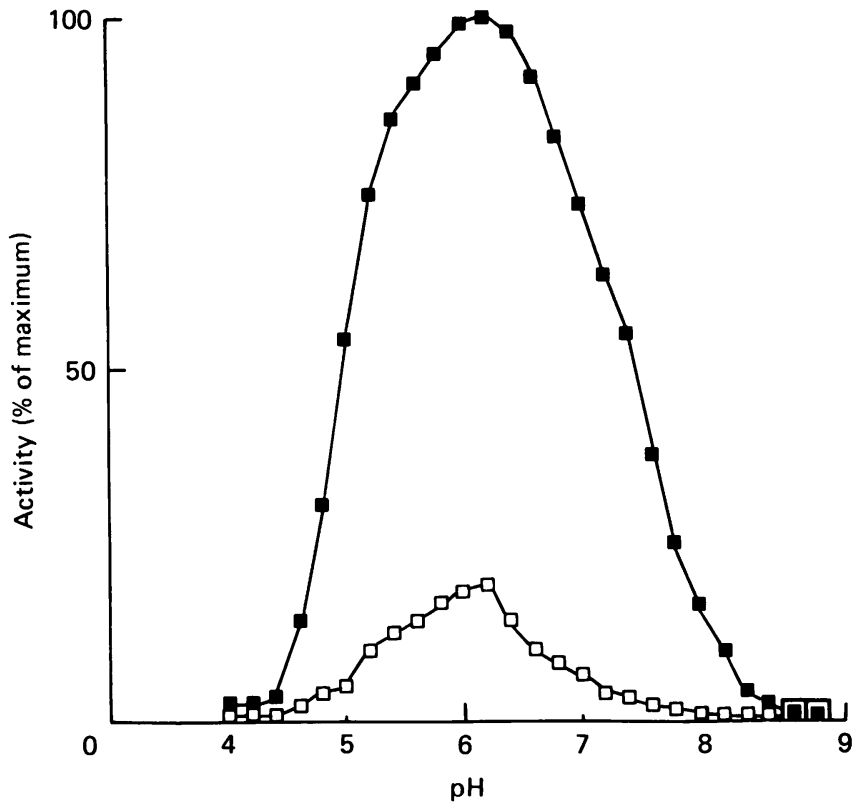

Fig. 4. Effect of pH and metal ions on activity of acid $p$-nitrophenyl phosphatase from bovine liver

The metal ions ( $\square, \mathrm{Zn}^{2+} ; \square, \mathrm{Mn}^{2+}$ ) were added to give a final concentration of $4 \mathrm{~mm}$. Assays were carried out at $37^{\circ} \mathrm{C}$ with $2.5 \mathrm{~mm}$-p-nitrophenyl phosphate in the following buffers: $50 \mathrm{~mm}$-acetate (pH 4-6), $25 \mathrm{~mm}$-barbital (pH 6-8.8) and 50 mM-glycine/ $\mathrm{NaOH}$ (pH 8.8-9).

On the basis of these findings, I conclude that bovine liver contains an acid p-nitrophenyl phosphatase form, which requires $\mathrm{Zn}^{2+}$ ions for its activity, and is different from those previously detected in mammalian tissues.

I thank Professor Derek Boothman for helpful criticism of the manuscript and Mr. Lanfranco Barberini for the excellent technical assistance. This work was supported by funds from the Italian Ministry of Education.

\section{REFERENCES}

Baldijao, C. E., Guija, E., Bittencourt, H.M.S. \& Chaimovich, H. (1975) Biochim. Biophys. Acta 391, 316-325

Campbell, N. D., Dudman, N.P.B. \& Zerner, B. (1973) FEBS Lett. 31, 123-126

Davis, B. J. (1964) Ann. N. Y. Acad. Sci. 121, 404-427

De Araujo, P. S., Mies, V. \& Miranda, O. (1976) Biochim. Biophys. Acta 425, 121-130

Di Pietro, D. L. \& Zengerle, F. S. (1967) J. Biol. Chem. 242, 3391-3396

Drysdale, J. W., Righetti, P. \& Bunn, H. F. (1971) Biochim. Biophys. Acta 229, 42-50

Gonzales, L. W. \& Meizel, S. (1973) Biochim. Biophys. Acta 320, $180-194$

Heinrikson, R. L. (1969) J. Biol. Chem. 244, 299-307

Hollander, P. V. (1971) Enzymes 3rd Ed. 4, 449-498

Igarashi, M. \& Hollander, P. W. (1968) J. Biol. Chem. 243, 6084-6089

Lawrence, E. L. \& Van Etten, R. L. (1981) Arch. Biochem. Biophys. 206, 122-131

Lowry, O. H., Rosebrough, N. J., Farr, A. L. \& Randall, R. J. (1951) J. Biol. Chem. 193, 265-275

Luchter-Wasyl, E. \& Ostrowsky, W. (1974) Biochim. Biophys. Acta 365, 349-359

Malik, N. \& Berrie, A. (1972) Anal. Biochem. 49, 173-176

Rehkop, D. M. \& Van Etten, R. L. (1975) Hoppe-Seyler's. Z Physiol. Chem 356, 1775-1782

Saini, M. S. \& Van Etten, R. L. (1978a) Arch. Biochem. Biophys. 191, 613-624

Saini, M. S. \& Van Etten, R. L. (1978b) Biochim. Biophys. Acta 526, 468-478

Shibko, S. \& Tappel, A. L. (1963) Biochim. Biophys. Acta 73, 76-86

Strittmatter, C. F. (1972) Biochim. Biophys. Acta 284, 196-207

Taga, E. M. \& Van Etten, R. L. (1982) Arch. Biochem. Biophys. 214, 505-515

Van Etten, R. L. \& McTigue, J. J. (1977) Biochim. Biophys. Acta 484, 386-397

Vanha-Perttula, T. (1970) Biochim. Biophys. Acta 227, 390-401

Wang, K. M. (1969) Biochem. J. 115, 191-197

Wilkinson, G. N. (1961) Biochem. J. 80, 324-332

Received 7 October 1985/25 November 1985; accepted 3 December 1985 